Research Paper

\title{
Organ Donation Knowledge and Attitudes among Health Science Students in Greece: Emerging Interprofessional Needs
}

Emmanouil K. Symvoulakis ${ }^{1}$, George Rachiotis ${ }^{2}$, Dimitrios Papagiannis ${ }^{2^{*}}$, Adelais Markaki $3^{* \bowtie}$, Yiannis Dimitroglou², Myfanwy Morgan ${ }^{4}$, Christos Hadjichristodoulou², Roger Jones ${ }^{5}$

1. Private Family Practice Unit in Heraklion, Crete, Greece

2. Department of Epidemiology and Hygiene, Faculty of Medicine, University of Thessaly, Greece

3. Department of Social Medicine, Faculty of Medicine, University of Crete, Greece

4. King's College London, Department of Primary Care and Public Health Sciences, London, UK

5. Emeritus Professor of General Practice, King's College London, UK

*equal contribution

$\triangle$ Corresponding author: Adelais Markaki, APRN-BC, PhD. Dept. of Social Medicine, Faculty of Medicine, Univ. of Crete, P.O. Box 2208, Heraklion, Crete, 71003. E-mail: adamarkaki@med.uoc.gr Tel. 0030-2810-394619

( ) Ivyspring International Publisher. This is an open-access article distributed under the terms of the Creative Commons License (http://creativecommons.org/ licenses/by-nc-nd/3.0/). Reproduction is permitted for personal, noncommercial use, provided that the article is in whole, unmodified, and properly cited.

Received: 20I4.0I.26; Accepted: 2014.04.04; Published: 20I4.04.25

\begin{abstract}
Background: The impact of presumed consent on donation rates has been widely debated. In June 2013 Greece adopted a 'soft' presumed consent law for organ and tissue donation, where relatives' approval is sought prior to organ removal.

Aims: To report on the knowledge, attitudes and concerns of undergraduate students, enrolled in three health science disciplines, in regards to organ donation and presumed consent.

Methods: Undergraduate junior and senior health science students [medical (MS), nursing (NS) and medical laboratory students (MLS)] were recruited from higher education settings in Thessaly, Greece. Dichotomous questions, previously used, were adopted to assess knowledge, attitudes and concerns towards organ donation, together with questions regarding the recent presumed consent legislation.

Results: Three hundred seventy-one out of 510 students participated in the study (response rate: $72.7 \%$ ). Only $3.6 \%$ of NS, $8.7 \%$ of MS and $3.2 \%$ of MLS carried a donor card. Although over $78 \%$ in all groups knew that it was possible to leave kidneys for transplant after death, only $10 \%$ to $39 \%$ considered themselves well-informed. NS were more likely to consider opting-out (21.5\%), followed by MLS (I7.9\%) and MS (I0.9\%). Respondents were more likely to refuse organ removal upon death when expressing one of the following views: a) opposing a system making it lawful to take kidneys from an adult who has just died, unless forbidden while alive [Odds ratio (OR) $95 \%$ Confidence Interval $(\mathrm{Cl}): 2.96(\mathrm{I} .48-5.93), \mathrm{p}=0.002$ ], b) worrying about their kidneys being removed after death [OR, 95\% Cl: $3.37(\mathrm{I} .75-6.49), \mathrm{p}=<0.00 \mathrm{I}]$ and $\mathrm{c}$ ) believing that an intact body was needed after death [OR, 95\% Cl: 4.23 (2.15-8.3I), $\mathrm{p}<0.00 \mathrm{I}]$.

Conclusion: Health science students, soon to become healthcare professionals, demonstrated limited awareness in regards to the newly reformed organ donation system. Identified knowledge deficits and concerns could have far-reaching implications in terms of conveying a clear message and shaping the public's stand. The feasibility and effectiveness of a joint inter-professional curriculum on organ and tissue donation issues across all three health science disciplines, addressing common themes and concerns deserves further study.
\end{abstract}

Key words: organ donation, knowledge, attitudes, interprofessional, Greece 


\section{Introduction}

The debate over the optimum ways to reform organ donation and transplantation legislation has been underscored by individual countries' successes and failures. A systematic literature review on the impact of presumed consent on donation rates concluded that presumed consent alone is unlikely to explain the variation between countries [1]. The availability of potential donors, transplantation infrastructure (capacity, coordination, training), healthcare expenditures, and public awareness/attitudes have also been identified as contributing factors. Thus, legislative reform alone is not sufficient to optimally change donation rates, as illustrated by the 'soft' (seeking relatives' approval) vs. 'hard' (without relatives' approval) presumed consent approach in Spain and Austria, respectively [2]. Contrary to widespread presumptions over the 'hard' version's greater effectiveness, in 2011 Austria reported 24.4 deceased donors per million population ( $\mathrm{pmp}$ ), whereas Spain reported 35.3 deceased donors pmp [3]. The donor rate record of Spain appears to be mostly attributed to the highly coordinated intensive care procurement network $[2,4,5]$.

Surveys vary in the level of support for presumed consent, with those conducted before the year 2000 reporting the lowest levels. During that period, only one third of the public in Hong Kong agreed with presumed consent and $20 \%$ indicated they would opt out if a new law was to be implemented [6]. Similarly support in the U.K. ranged from $28-57 \%$, with a reported upward shift from 2000 onwards [1]. In a 2012 survey in Hong Kong, 76.5\% of respondents were inclined to donate their own kidneys, with even higher percentages consenting to donate a deceased family member's kidneys [7]. At the same time, intention for opt-out among people in Hong Kong was much lower $(7.18 \%)$, weakening the claim that an opt-out system may reduce donation rates and patients' autonomy. Even so, there are still some reservations in terms of human freedom ramifications, as illustrated by Wale's well-in-advance planning of a two-year information campaign before transitioning to a new system of 'deemed consent' in December, 2015 [8].

As of June 2013, Greece has adopted a 'soft' presumed consent law, while in the midst of an unprecedented financial and social uncertainty [9]. A series of recent studies in an array of healthcare settings have attempted to shed light on the main factors impacting organ and tissue donation rates in Greece [10-17]. Their findings have been disturbing in terms of low organ donation rates, but not unexpected, given the fragmentation of healthcare services, the haphazard nature of attempted reform and the absence of extensive debate among policy makers, healthcare professionals and the public. The implied shortcomings of Greek undergraduate medical and nursing curricula in systematically addressing issues of organ donation promotion, recruitment, procurement and donor/recipient needs were particularly intriguing $[16,18]$.

Several studies over the last 15 years have focused on the learning needs, attitudes and viewpoints of undergraduate health science students in regards to donation and opt-in vs. opt-out systems [19-31]. Despite the somewhat mixed findings, there seems to be consensus on the importance of early exposure in preparing the future role models for the general public. However, in most studies the type and extent of exposure has been an educational intervention targeting a single discipline, medicine $[20,23,24]$ or nursing $[28,31]$, rather than multiple health science disciplines $[25,30]$.

This article aims to report on the prevailing knowledge, attitudes and concerns of undergraduate students, enrolled in three distinct health science disciplines, in regards to organ donation and presumed consent during transition to a new legislative framework.

\section{Methods}

\section{Sample recruitment}

Undergraduate junior and senior health science students were recruited as a convenience sample from the following higher education settings in the region of Thessaly in mainland Greece: 1) Medical students $\left(^{\text {th }}\right.$ and $6^{\text {th }}$ year) from the Faculty of Medicine, School of Health Sciences, University of Thessaly, 2) Nursing students ( $3^{\text {rd }}$ and $4^{\text {th }}$ year) from the Department of Nursing, Technological Educational Institute (TEI) of Thessaly, and 3) Medical Laboratory students ( $3^{\text {rd }}$ and $4^{\text {th }}$ year) from the Department of Medical Laboratories, Technological Educational Institute of Thessaly. Both departments from TEI of Thessaly were part of the School of Health and Welfare Professions. Annual admission by discipline was 120 medical students (MS), 180 nursing (NS) and 220 medical lab students (MLS). Inclusion criteria for participation were: 1) enrollment in junior or senior class courses, and 2) in-person class attendance during the specified 10-week data collection period.

\section{Data collection and Ethics}

Following previous research conducted in Greece, an adapted questionnaire, originally developed by Morgan and colleagues to study kidney donation among ethnic groups in the UK, was used [32]. 
The questionnaire comprised of 21 items, grouped in three main domains: knowledge, general attitudes to kidney donation, and specific concerns. Supplementary questions, used among general practice patients [17], were also employed to assess attitudes towards blood donation as well as awareness, specific concerns and intentions towards presumed consent. Socio-demographic information such as age, sex, religious affiliation and nationality was also registered (see Table 1).

Data were collected from March through May 2013 and each participant was assigned a code number for data entry and analysis. A total of 510 questionnaires were distributed to eligible students during in class teaching sessions in the targeted schools. Upon assuring that participation was voluntary and that responses would be anonymous and confidential, return of a completed questionnaire indicated informed consent. Study approval was received from the University of Thessaly, Medical Faculty Ethics Committee (Larissa, November 2012).

\section{Statistical analysis}

Data were tabulated using the Epi info statistical package (TM) 3.5.4. Questionnaire items that were not fully or clearly completed were reported as missing values. Variables were presented as counts and proportions. Chi square test was used for qualitative data. P-values were considered statistically significant if $P<0.05$. Nine pre-defined variables (Table 2 items $\# 5,7,9,12,13,14,15,18,19)$ were tested in univariate analysis in regards to respondents' intention to prohibit organ removal within the newly established opt-out organ donation system (Table 3 item \#4). Backward logistic regression analysis was then performed to explore potential independent associations with respondents' intention to prohibit organ removal.

\section{Results}

\section{Characteristics of respondents}

A total of 371 out of 510 students returned a completed questionnaire (response rate: $72.7 \%$ ). Response rate by discipline was $80 \%(104 / 130)$ for medical students, $69.3 \%(111 / 160)$ for nursing, and $70.9 \%$ $(156 / 220)$ for medical lab students. Respondent demographic characteristics are presented in Table $\mathbf{1}$. Respondents were mostly women with a mean age of 22.1 years (SD: 3.06) for nursing students, 23.6 years (SD: 3.02) for medical students and 21.3 years (SD: 2.29) for medical lab students. Among MLS and NS, $148(94.9 \%)$ and $105(94.6 \%)$ respectively were self-classified as Christian-Orthodox compared to 93 $(89.4 \%)$ of MS.
Table I: Socio-demographic profile of undergraduate health science students

\begin{tabular}{llll}
\hline $\begin{array}{l}\text { Socio-demographic charac- } \\
\text { teristics }\end{array}$ & $\begin{array}{l}\text { Nursing } \\
\text { students } \\
\text { (NS) } \\
\mathbf{n}(\%)\end{array}$ & $\begin{array}{l}\text { Medical } \\
\text { students } \\
\text { (MS) } \\
\mathbf{n}(\%)\end{array}$ & $\begin{array}{l}\text { Medical Labora- } \\
\text { tory students } \\
\text { (MLS) }\end{array}$ \\
\hline $\begin{array}{l}\text { Age (years) } \\
\text { Gender }\end{array}$ & $22.1(3.06)$ & $23.6(3.02)$ & $21.3(2.29)$ \\
$\begin{array}{l}\text { Male } \\
\text { Female } \\
\text { Religious Affiliation }\end{array}$ & $13(11.7 \%)$ & $43(41.3 \%)$ & $39(25 \%)$ \\
$\begin{array}{l}\text { Orthodox } \\
\begin{array}{l}\text { Non-Orthodox (including } \\
\text { atheists) }\end{array}\end{array}$ & $105(88.3 \%)$ & $61(58.7 \%)$ & $117(75 \%)$ \\
$\begin{array}{l}\text { Nationality } \\
\text { Greek }\end{array}$ & $6(5.4 \%)$ & $11(10.6 \%)$ & $8(5.1 \%)$ \\
Other than Greek & $106(95.5 \%)$ & $102(98.1 \%)$ & $138(89 \%)$ \\
\hline & $5(4.5 \%)$ & $2(1.9 \%)$ & $17(11 \%)$ \\
\hline
\end{tabular}

\section{Knowledge, attitudes and specific concerns to kidney organ donation}

Table 2 shows that only $3.6 \%$ (4/111) of NS, $8.7 \%$ (9/104) of MS and 5/156 (3.2\%) of MLS carried a donor card. Although over $78 \%$ in all groups knew that it was possible to leave kidneys for transplant after death (item \#2), and over $60 \%$ had thought about it (item \#5), only a small proportion, ranging from $10 \%$ to $39 \%$, considered themselves well-informed to actually register as a kidney donor.

Half of MS would be willing to register as a donor if it was not necessary to carry a donor card, a statistically significant difference from the other two groups. At least one third of students among all groups had discussed the issue of donating kidneys with family or friends. Nevertheless, oposition to a system that would make it lawful to take kidneys from an adult who has just died, unless otherwise forbidden, was stronger among NS (62/110, 56.4\%) and MLS (84/155, 54.2\%), with MS scoring lower $(48 / 104,46.2 \%)$.

Nursing students were more likely to mind who received their kidneys after death (item \#10), differing statistically significant from the other two groups. Almost three out of ten respondents were concerned that carrying a donor card was like tempting death (item \#17). Nursing students' positive responses to item \#16 "Do you think that registering to be a donor is like tempting death?" and item \#19 "Do you think an intact body is needed after death?" were statistically significant different than those of the other two groups. The majority of students from all groups agreed that they would become a live donor if a young child or adult required a kidney (items \#20, 21). 
Table 2: Kidney organ donation knowledge, attitudes and concerns by health science student category $(* \mathrm{P}<0.05, * * \mathrm{P}<0.00 \mathrm{I})$

\begin{tabular}{|c|c|c|c|}
\hline Questionnaire domains / items & $\begin{array}{l}\text { Nursing students' } \\
\text { positive responses } \\
\text { n ( } \%)\end{array}$ & $\begin{array}{l}\text { Medical students' } \\
\text { positive responses } \\
\text { n }(\%)\end{array}$ & $\begin{array}{l}\text { Medical Laboratory } \\
\text { students' } \\
\text { positive responses } \\
\text { n }(\%)\end{array}$ \\
\hline \multicolumn{4}{|l|}{ Knowledge } \\
\hline $\begin{array}{l}\text { 1. Are you registered on the national organ donor register and do you carry a donor } \\
\text { card? }\end{array}$ & $4 / 111(3.6 \%)$ & $9 / 104(8.7 \%)$ & $5 / 156(3.2 \%)$ \\
\hline 2. Did you know it was possible to leave kidneys for transplant after death? & $88 / 111(79.3 \%)$ & $92 / 104(88.5 \%)$ & $130 / 156(83.3 \%)$ \\
\hline 3. Do you feel well informed about registering as a kidney donor? & $12 / 111(10.8 \%)$ & $13 / 102(12.7 \%)$ & $16 / 155(39 \%)$ \\
\hline 4. Do you know anyone who has received or is waiting to receive a kidney? & $18 / 111(16.2 \%)$ & $20 / 104(19.2 \%)$ & $24 / 155(15.5 \%)$ \\
\hline \multicolumn{4}{|l|}{ General attitudes } \\
\hline 5. Have you ever thought about donating kidneys after death? & $67 / 111(60.4 \%)$ & $76 / 104(73.1 \%)$ & $99 / 156(63.5 \%)$ \\
\hline $\begin{array}{l}\text { 6. Would you be willing to register as kidney donor and donate kidneys for transplant } \\
\text { after death? }\end{array}$ & $58 / 108(53.7 \%)$ & $61 / 104(58.7 \%)$ & $90 / 153(58.8 \%)$ \\
\hline 7. Have you ever discussed donating kidneys with partner, family member or friend? & $42 / 111(37.8 \%)$ & $43 / 104(41.3 \%)$ & $61 / 156(39.1 \%)$ \\
\hline $\begin{array}{l}\text { 8. Would you be willing to register as a donor if it was not necessary to carry a donor } \\
\text { card? }\end{array}$ & $34 / 110(30.9 \%)^{*}$ & $52 / 103(50.5 \%)$ & $64 / 154(41.6 \%)$ \\
\hline $\begin{array}{l}\text { 9. Would you oppose a system that made it lawful to take kidneys from an adult who has } \\
\text { just died unless that person had forbidden it while he was alive? }\end{array}$ & $62 / 110(56.4 \%)$ & $48 / 104(46.2 \%)$ & $84 / 155(54.2 \%)$ \\
\hline \multicolumn{4}{|l|}{ Specific concerns } \\
\hline 10. If a kidney donor, would you mind who received your kidneys after your death? & $45 / 111(40.5 \%)^{*}$ & $22 / 104(21.2 \%)$ & $43 / 156(27.6 \%)$ \\
\hline $\begin{array}{l}\text { 11. Do you agree that it is important to know that someone else is given a chance of life } \\
\text { after donor's death? }\end{array}$ & $108 / 111(97.3 \%)$ & $96 / 104(92.3 \%)$ & $145 / 155(93.5 \%)$ \\
\hline $\begin{array}{l}\text { 12. Are you confident that medical teams will try as hard to save the life of a person who } \\
\text { has agreed to donate organs? }\end{array}$ & $52 / 111(46.8 \%)$ & $53 / 103(51.5 \%)$ & $64 / 153(41.8 \%)$ \\
\hline 13. Are you worried about your kidneys being removed after death? & $34 / 110(30.9 \%)$ & $25 / 103(24.3 \%)$ & $35 / 156(22.4 \%)$ \\
\hline $\begin{array}{l}\text { 14. Do you worry that donated organs might be used without consent for other purposes } \\
\text { like medical research? }\end{array}$ & $92 / 110(83.6 \%) * *$ & $56 / 104(53.8 \%)$ & $111 / 156(71.2 \%)$ \\
\hline 15. Do you find organ donation unacceptable because of religious beliefs? & 22/111 (19.8\%) & 19/104 (18.3\%) & $42 / 155(27.1 \%)$ \\
\hline 16. Do you think that registering to be a donor is like tempting death? & $34 / 109(31.2 \%)^{*}$ & $16 / 103(15.5 \%)$ & $37 / 155(23.9 \%)$ \\
\hline 17. Do you think that carrying a donor card is like tempting death? & $37 / 110(33.6 \%)$ & $23 / 104(22.1 \%)$ & $45 / 156(28.8 \%)$ \\
\hline 18. Do you agree that donating organs when you die is a good thing to do? & $108 / 111(97.3 \%)$ & 103/104 (99\%) & $153 / 156(98.1 \%)$ \\
\hline 19. Do you think that an intact body is needed after death? & $28 / 110(25.5 \%)^{*}$ & $14 / 104(13.5 \%)$ & $39 / 156(25 \%)$ \\
\hline 20. Would you consider becoming a live donor if a young child required a kidney? & $96 / 110(87.3 \%)$ & $88 / 104(84.6 \%)$ & $133 / 153(86.9 \%)$ \\
\hline 21. Would you consider becoming a live donor if an adult required a kidney? & $82 / 108(75.9 \%)$ & $84 / 104(80.8 \%)$ & $114 / 154(74 \%)$ \\
\hline
\end{tabular}

\section{Awareness and stand towards organ/tissue donation}

As shown in Table 3, there was a statistically significant difference $(p<0.05)$ among the three student groups in terms of being a blood donor. One third of MS (33/103, 32\%) declared being a blood donor, compared to $18 \%(20 / 111)$ of NS and $14.3 \%$ (22/154) of MLS. Also, significantly more MS than NS and MLS $(36.6 \%$ vs. $16.2 \%$ and $16.2 \%$, p<0.001) knew that national legislation on organ donation has recently changed. In terms of students' intentions to opt-out (item \#4), although there was no statistically significant difference among the three groups, NS answered more frequently positively $(21.5 \%)$, followed by MLS (17.9\%) and last, by MS (10.9\%).

\section{Intention to opt-out}

Multivariate analysis (backward logistic regression analysis) for Table 2 items \#5,7,9,12,13,14,15,18 and 19 to detect possible correlations with respondents' intention to prohibit organ removal within the newly established opt-out organ donation system
(Table 3 item \#4) demonstrated significant correlations for the following items:

\#9 "Would you oppose a system that made it lawful to take kidneys from an adult who has just died unless that person had forbidden it while he was alive?"

\#13 “Are you worried about your kidneys being removed after death?"

\#19 "Do you think that an intact body is needed after death?"

Table 4 shows that respondents opposing a system making it lawful to take kidneys from an adult who has just died, unless forbidden while alive, were more likely to prohibit organ removal upon death [Odds ratio (OR) 95\% Confidence Interval (CI): 2.96 (1.48-5.93), $p=0.002]$. Those worrying about their kidneys being removed after death were also more prone to prohibit organ removal upon death [OR, 95\% CI: 3.37 (1.75-6.49), $p=<0.001]$. Furthermore, respondents who believed that an intact body was needed after death were 4 times more likely to refuse organ removal upon death [OR, 95\% CI: 4.23 $(2.15-8.31), \mathrm{p}<0.001]$. 
Table 3: Organ/tissue donation awareness and stand by health science student category

\begin{tabular}{|c|c|c|c|c|}
\hline Supplementary Questionnaire items & $\begin{array}{l}\text { Nursing students' } \\
\text { positive responses }\end{array}$ & $\begin{array}{l}\text { Medical students' } \\
\text { positive responses }\end{array}$ & $\begin{array}{l}\text { Medical Lab students' } \\
\text { positive responses }\end{array}$ & P value \\
\hline 1. Are you a volunteer blood donor? & $20 / 111(18 \%)$ & $33 / 103(32 \%)$ & $22 / 154(14.3 \%)$ & $<0.05$ \\
\hline 2. Are you aware that organ donation legislation has recently changed? & $18 / 111(16.2 \%)$ & $37 / 101(36.6 \%)$ & $25 / 154(16.2 \%)$ & $<0.001$ \\
\hline $\begin{array}{l}\text { 3. Do you feel well informed about the new law in regards to organ } \\
\text { donation and presumed consent? }\end{array}$ & $9 / 110(8.2 \%)$ & $6 / 103(5.8 \%)$ & $9 / 154(5.8 \%)$ & NS \\
\hline $\begin{array}{l}\text { 4. Do you intent to carry out your right to prohibit the removal of your } \\
\text { organs upon death? }\end{array}$ & $23 / 107(21.5 \%)^{*}$ & $11 / 101(10.9 \%)$ & 27/151 (17.9\%) & NS \\
\hline $\begin{array}{l}\text { 5. Have you discussed with your partner, family members or friends } \\
\text { your intentions in regards to presumed consent? }\end{array}$ & $29 / 110(26.4 \%)$ & $34 / 103(33 \%)$ & $37 / 154(24 \%)$ & NS \\
\hline
\end{tabular}

Table 4: Intention to opt-out by general attitude and specific concerns (backward logistic regression analysis)

\begin{tabular}{|c|c|c|}
\hline \multirow[t]{2}{*}{ General attitude and specific concerns (Questionnaire items) } & \multicolumn{2}{|c|}{$\begin{array}{l}\text { Intention to prohibit organ removal upon death (Supplementary Questionnaire } \\
\text { item \#4) }\end{array}$} \\
\hline & OR $(95 \% \mathrm{CI})$ & Pvalue \\
\hline \multicolumn{3}{|c|}{$\begin{array}{l}\text { Item \#9: Would you oppose a system that made it lawful to take kidneys from } \\
\text { an adult who has just died unless that person had forbidden it while he was } \\
\text { alive? }\end{array}$} \\
\hline Yes & $2.96(1.48-5.93)$ & 0.002 \\
\hline No & 1.00 (ref) & \\
\hline \multicolumn{3}{|c|}{ Item \# 13: Are you worried about your kidneys being removed after death? } \\
\hline Yes & $3.37(1.75-6.49)$ & $<0.001$ \\
\hline \multicolumn{3}{|l|}{ No } \\
\hline \multicolumn{3}{|l|}{ Item \# 19: Do you think that an intact body is needed after death? } \\
\hline Yes & $4.23(2.15-8.31)$ & $<0.001$ \\
\hline No & & \\
\hline
\end{tabular}

\section{Discussion}

This study provides a detailed analysis of the Greek health sciences student community just before a transition towards a new organ procurement system occurred. Across all three groups, more than half of students were willing to register as deceased kidney donors. However, only a small proportion of students were sufficiently well-informed to actually register. Twice as many medical students carried a donor card compared to nursing and medical lab students (8.7\% vs $3.6 \%$ and $3.2 \%$, respectively). Yet, the overall number of donor card holders remained very low, with almost three out of ten students perceiving the act of carrying a donor card as tempting death. These outcomes are not unexpected given that Greek undergraduate curricula in medicine, nursing and other health disciplines do not systematically address organ donation $[16,18]$.

The above findings are also in agreement with those from a Greek general hospital study in the following aspects: 1 ) healthcare professionals were eager to register, but admitted having limited knowledge about registering as a kidney donor, 2) more physicians $(7 \%)$ than nurses $(3 \%)$ declared holding donor cards, 3) overall registration rates were lower than expected [16]. In another Greek general practice study, patients with a donor card accounted for only $2.6 \%$, with one out of four intending to carry out their right to prohibit organ removal upon death [17]. The strong association between possession of an organ donor card (informed group) and the willingness to donate organs has been shown in a German study among public officials [33].

In terms of awareness of the new organ donation legislation, initiated in June 2013, overall ratings were low, ranging from $36.6 \%$ for MS to $16.2 \%$ for NS and MLS. In a 2011 study of Greek medical students, a staggering $78.9 \%$ claimed ignorance of the new legislation [18]. Greek medical students' level of self-reported awareness was lower than the reported level in other European countries. French first-year medical students reported $51 \%$ awareness, Swiss first-year MS 44\%, whereas Polish MS only 23\% [19]. Similarly, awareness of new legislation among Greek general practice patients during the transition period from an opt-in to an opt-out system was a mere $9.6 \%$, whereas only $3.8 \%$ considered the public adequately informed [17]. Our findings are in contrast to the reported current level of awareness among Austrian patients, students and ICU nurses, a remarkable $84 \%$ [19].

In terms of attitudes, opposition to presumed consent in regards to kidney removal from a deceased person was stronger among NS and MLS with MS scoring lower. Students opposing to presumed consent, worrying about their kidneys being removed after death, or believing that an intact body was needed after death, were more likely to refuse organ removal upon death. The utility of this finding in the 
form of a 3-item tool to pre-assess the likelihood for opt-out among individuals or groups, while avoiding asking a direct question that may lead to socially expected responses, could be promising.

In our study, despite more than half of all students being willing to register as kidney donors, still $13 \%$ of MS and $25 \%$ of NS and MLS wanted to be buried with all their organs intact. Our respondents' ambivalence was not unique. A Romanian study of medical students reported 38\% unwillingness or hesitancy to donate an organ, with desire for body integrity preservation and respect toward the deceased person being the most frequent reasons for denial [22]. Similarly, in a study of Hong Kong MS, the traditional Chinese belief in preservation of an intact body after death, unease discussing death-related issues, and family objections to organ donation were significantly associated with a negative attitude [26].

Although further research across various cultural and religious groups is needed, the potential benefits of increasing awareness as early as possible among health science students and professionals merit immediate attention. Early exposure during undergraduate studies may strengthen nurses' ability to identify and refer potential donors once they are in practice [34]. Depending on the country's legislative framework and the establishment of a national procurement system, nursing students' awareness varies from inadequate, according to a study from Italy [29], to more favorable attitudes and greater awareness, as shown in a study from Spain [31]. Hence, organ procurement organizations in the US strive to provide relevant education to both medical and nursing students, using a standardized approach to facilitate the process and avoid draining their precious resources [34].

Several health science schools in the US include an organ donation component, with most schools relying on lectures as the sole method of instruction. According to a 2009 survey of medical and nursing school deans responsible for curriculum development and evaluation, a significant proportion of institutions failed to provide instruction on donation consent processes, definitions of brain and cardiac death, and the discussion of organ donation during a routine health care visit [35]. Conventional educational interventions, namely lectures and presentations, appear to meet medical and nursing students' information needs but have little effect on their attitude towards organ donation [24,28]. In contrast, unconventional experience from a US osteopathic school offering a module with the use of a standardized patient, an actor portraying a living donor candidate, as well as supplementary instructional materials (film, panel discussion, reading list) has been promising [23].

\section{Implications}

Our preliminary findings indicate potential common ground concerning students' knowledge deficits, concerns or misconceptions across all three health science disciplines in regards to organ/tissue donation and the procurement system. As a next step, the necessity, feasibility and effectiveness of a joint interprofessional curriculum for undergraduate senior health science students should be explored.

\section{Study Limitations}

Although three different health science departments were targeted, all were within the same geographical region. This localized data source reduces possibilities of generalizability, mandating future expansion of this study in other geographical areas. However, given our consistent past findings there is no reason to expect that overall knowledge, attitudes and concerns of Greek undergraduate health science students would be notably different at a national level.

It is plausible that interactions among respondents might have occurred, influencing students' responses. Despite the high response rate $(72.7 \%)$, bias introduced through an under-representation of academically below-average students cannot be ruled out. Since class attendance is not mandatory for all courses, it is reasonable to ascertain that only students who were academically more committed met the study's eligibility criteria. No data on the profile of non-respondents and their reasons to deny participation were available. Thus, the profile of ineligible or non-responding students would need to be examined in greater depth before planning any educational initiatives.

\section{Conclusion}

An opt-out system's success requires systematic and continuous efforts to raise public awareness and overcome misconceptions. Appropriate knowledge and a positive attitude by health science students could play a key role in shaping public opinion. Further systematic interprofessional actions in the academic setting could nurture a more favorable attitude towards organ donation. A joint curriculum for addressing knowledge deficits, general concerns and negative attitudes across senior health science students deserves immediate consideration.

\section{Acknowledgements}

The authors would like to thank the administration of each higher education setting involved, for 
facilitating the conduct of this study as well as all participating students for taking the time to complete this survey.

\section{Authors' contributions}

EKS conceived the study idea. EKS, GR, AM, RJ, $\mathrm{MM}$ and $\mathrm{CH}$ were involved with study details. RG, DP and YD performed data acquisition. RG carried out data tabulation and statistical analysis. EKS, AM provided technical support, performed the literature search and prepared the first draft. RJ, $\mathrm{CH}$ and $\mathrm{MM}$ offered useful intellectual insights, technical advice, content and editing improvements. All authors contributed to the final version and approved the manuscript.

\section{Competing Interests}

The authors have declared that no competing interest exists.

\section{References}

1. Rithalia A, McDaid C, Suekarran S, Myers L, Sowden A. Impact of presumed consent for organ donation on donation rates: a systematic review. BMJ. 2009 Jan 14;338:a3162.

2. McGlade D, Rae G, McClenahan C, Pierscionek B. Regional and temporal variations in organ donation across the UK (secondary analyses of databases). BMJ Open. 2011 Jan 1;1(2):e000055.

3. [Internet] European Commission. Organ donation and transplantation: facts and figures; 9 Oct. 2012; Journalists' Workshop. http://ec.europa.eu/ health/blood_tissues_organs/docs/ev_20121009_facts_figures.pdf

4. Matesanz R, Marazuela R, Domínguez-Gil B, et al. The 40 donors per million population plan: an action plan for improvement of organ donation and transplantation in Spain. Transplant Proc 2009;41:3453-6.

5. Fabre J, Murphy P, Matesanz R. Presumed consent: a distraction in the quest for increasing rates of organ donation. BMJ 2010;341:c4973.

6. Li PK, Lin CK, Lam PK, et al. Attitudes about organ and tissue donation among the general public and blood donors in Hong Kong. Prog Transplant 2001;11:98-103.

7. Chan TK, Cowling BJ, Tipoe GL. A public opinion survey: is presumed consent the answer to kidney shortage in Hong Kong? BMJ Open. $2013 \operatorname{Jan} 3 ; 3(1)$

8. [Internet] National Assembly of Wales. Human Transplantation (Wales) Act 2013. http://www.senedd.assemblywales.org/mgIssueHistoryHome.aspx? IId $=5178$

9. Symvoulakis EK, Markaki A, Morgan M, Jones P. Organ donation during economic hardship: an untold end for Prometheus? BMI Rapid Response 26-5-2011. http://www.bmj.com/content/342/bmj.d982?tab=responses

10. Karatzas T, Menoudakou G, Chatzixiros E, Kyrkou B, Maleskou S, Kostakis A. Improving the organ transplantation program in Greece: institution of local transplant coordinators' network. Transplant Proc. 2007 May;39(4):793-6.

11. Marantidou O, Loukopoulou L, Zervou E, Martinis G, Egglezou A, Fountouli P, Dimoxenous P, Parara M, Gavalaki M, Maniatis A. Factors that motivate and hinder blood donation in Greece. Transfus Med. 2007 Dec;17(6):443-50.

12. Galanis PA, Sparos LD, Katostaras T, Velonakis E, Kalokerinou A. Factors that influence Greeks' decision to register as potential bone marrow donors. Transplant Proc. 2008 Jun;40(5):1271-4.

13. Symvoulakis EK, Komninos ID, Antonakis N, Morgan M, Alegakis A, Tsafantakis E, Chatziarsenis M, Philalithis A, Jones R. Attitudes to kidney donation among primary care patients in rural Crete, Greece. BMC Public Health. 2009 Feb 10:9:54

14. Symvoulakis EK, Stavroulaki E, Morgan M, Jones R. Kidney organ donation: developing family practice intiatives to reverse inertia. BMC Health Serv Res. 2010;10:127.

15. Georgiadou E, Sounidakis N, Mouloudi E, Giaglis P, Giasnetsova T, Marmanidou K, Gritsi-Gerogianni N. Attitudes and behavior toward organ donation in Greece. Transplant Proc. 2012 Nov;44(9):2698-701.

16. Symvoulakis EK, Tsimtsiou Z, Papaharitou S, Palitzika D, Markaki A, Stavroulaki E, Morgan M, Jones R. Kidney organ donation knowledge and attitudes among health care professionals: findings from a Greek general hospital. Appl Nurs Res. 2012 Nov;25(4):283-90.

17. Symvoulakis EK, Markaki A, Galanakis C, Klinis S, Morgan M, Jones R. Shifting towards an Opt-Out System in Greece: A General Practice Based Pilot Study. Int J Med Sci. 2013 Sep 1;10(11):1547-51.
18. Dardavessis $\mathrm{T}$, Xenophontos $\mathrm{P}$, Haidich $\mathrm{AB}$, Kiritsi $\mathrm{M}$, Vayionas MA Knowledge, attitudes and proposals of medical students concerning transplantations in Greece. Int J Prev Med. 2011;2(3):164-169.

19. Stadlbauer V, Steiner P, Schweiger M, Sereinigg M, Tscheliessnigg KH, Freidl W, Stiegler P. Knowledge and attitude of ICU nurses, students and patients towards the Austrian organ donation law. BMC Med Ethics. 2013 Aug 16;14:32.

20. Essman CC, Lebovitz DJ. Donation education for medical students: enhancing the link between physicians and procurement professionals. Prog Transplant. 2005 Jun;15(2):124-8

21. Figueroa CA, Mesfum ET, Acton NT, Kunst AE. Medical students' knowledge and attitudes toward organ donation: results of a Dutch survey. Transplant Proc. 2013;45(6):2093-7.

22. Jung H. Reluctance to donate organs: a survey among medical students. Transplant Proc. 2013 May;45(4):1303-4.

23. Bramstedt KA, Moolla A, Rehfield PL. Use of standardized patients to teach medical students about living organ donation. Prog Transplant. 2012 Mar;22(1):86-90.

24. Radunz S, Juntermanns B, Heuer M, Frühauf NR, Paul A, Kaiser GM. The effect of education on the attitude of medical students towards organ donation. Ann Transplant. 2012;17(1):140-4.

25. Manyalich M, Paredes D, Ballesté C, Menjívar A. The PIERDUB project: International Project on Education and Research in Donation at University of Barcelona: training university students about donation and transplantation. Transplant Proc. 2010;42(1):117-20.

26. Chung CK, Ng CW, Li JY, Sum KC, Man AH, Chan SP, Cheung JY, Yu KP, Tang BY, Lee PP. Attitudes, knowledge, and actions with regard to organ donation among Hong Kong medical students. Hong Kong Med J. 2008 Aug;14(4):278-85.

27. Tam WW, Suen LK, Chan HY. Knowledge, attitudes and commitment toward organ donation among nursing students in Hong Kong. Transplant Proc. 2012 Jun;44(5):1196-200.

28. Whisenant DP, Woodring B. Improving attitudes and knowledge toward organ donation among nursing students. Int J Nurs Educ Scholarsh. 2012 Sep 13;9:22.

29. Zampieron A, Corso M, Frigo AC. Undergraduate nursing students' attitudes towards organ donation: a survey in an Italian university. Int Nurs Rev. 2010 Sep;57(3):370-6.

30. Rykhoff ME, Coupland C, Dionne J, Fudge B, Gayle C, Ortner TL, Quilang K, Savu G, Sawany F, Wrobleska M. A clinical group's attempt to raise awareness of organ and tissue donation. Prog Transplant. 2010 Mar;20(1):33-9.

31. López-Montesinos MJ, Manzanera Saura JT, Mikla M, Ríos A, López-Navas A, Martínez-Alarcón L, Rodríguez MM, Ramírez P. Organ donation and transplantation training for future professional nurses as a health and social awareness policy. Transplant Proc. 2010;42(1):239-42.

32. Morgan M, Hooper R, Mayblin M, Jones R. Attitudes to kidney donation and registering as a donor among ethnic groups in the UK. Public Health (Oxf). 2006;28:226-234.

33. Heuer M, Hertel S, Wirges U, Philipp T, Gerken G, Paul A, Kaiser GM: Evaluation of organ donor card holders among public officials of a major German city. Transplant Proc 2009, 41(6):2505-2508.

34. Van Da Walker SG. Standardizing donation education for nursing students: one organ procurement organization's approach. J Transpl Coord. 1998 Jun;8(2):93-6.

35. Anker AE, Feeley TH, Friedman E, Kruegler J. Teaching organ and tissue donation in medical and nursing education: a needs assessment. Prog Transplant. 2009 Dec;19(4):343-8 